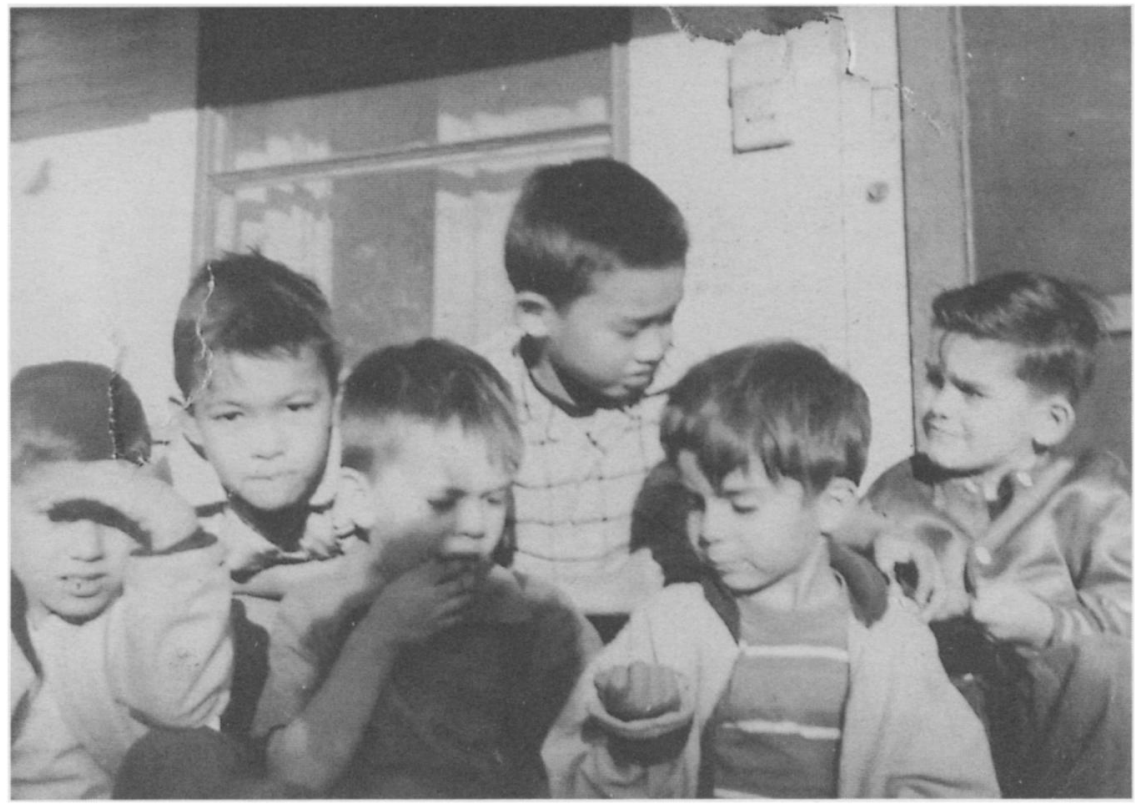

The Mexican Little Rascals, circa 1957: from left to right, Rick Soto, Arnold Molina, Lloyd Molina, unidentified friend, Gary Soto, and Issac Esparza. 


\section{The Childhood Worries, Or Why I Became a Writer - Gary Soto}

AS A BOY GROWING UP in Fresno I knew that disease lurked just beneath the skin, that it was possible to wake in the morning unable to move your legs or arms or even your head, that stone on a pillow. Your eyeballs might still swim in their own liquids as they searched the ceiling, or beyond, toward heaven and whatever savage god did this to you. Frail and whimpering, you could lie in your rickety bed. You could hear the siren blast at the Sun-Maid Raisin plant, and answer that blast with your own chirp-like cry. But that was it for you, a boy now reduced to the dull activity of blinking. In the adjoining rooms, a chair scraped against the linoleum floor, the kitchen faucet ran over frozen chicken parts, the toilet flushed, the radio sputtered something in Spanish. But you were not involved. You lay useless in bed while your family prepared for the day.

Disease startled Uncle Johnnie first, a mole on his forearm having turned cancerous and bright as a red berry. He was living in Texas when he wrote my mother about his illness. We took him in in spring. He lived with us the last three months of his life, mostly lying ill on the couch, a space meant for my brother Rick and me. Before our uncle arrived, we jumped on that couch, me with a flea-like leap and my brother with the heavier bounce of a frog. Now he had the couch to himself, this uncle who was as tender as a pony.

I didn't have much memory to go on. At age six, I didn't lie in bed at night, arms folded behind my head, and savor the time when I was four and a half, a sprout of orneriness. I was too busy in my young body to consider my trail of footprints, all wiped out at the end of a day. But I recall Uncle Johnnie and the apple pie he bought me at Charlie's Market. My greed for sweetness grinned from my sticky mouth, and we devoured the pie as we strolled home, I walking backwards and looking at the market. Later I would return to that market and let my hands settle like small crabs on two candy bars. They opened and closed around them as I decided whether to take them, thus steal, thus let my mouth lather itself with the creamy taste of chocolate. Charlie was probably looking at me, wagging his large Armenian head at my stupidity. But that wasn't the point: I was deciding 
for myself whether I should sin and then worry about this sin, the wings of my bony shoulder blades less holy.

I recall also when our television was broken and my father pulled the tube out and took it to a repair shop. The TV was eyeless, just sprouts of wires and a smothering scent of dust. While Uncle Johnnie lay on the couch, I climbed into the back of the television set and pretended to be someone funny, one of the Three Stooges, and then someone scary, like Rodan with his monstrous roar. My uncle watched me with a weary smile but no joy. I told him that I could be funny or scary, but in such a small space I couldn't play a horse or an Indian shot by the cavalry. He died that spring, all because of a cancerous mole, died after the tube was once again fitted into the television set. Then the couch returned to us.

For one summer disease scared me. My whiskery neighbor, whose name I have forgotten, was a talker and addressed every growing plant, chicken, and dog in his dirt yard. When he got sick his talk increased, as if he needed to get out all the words that he had intended to use in his old age. He had to use them then or never. One afternoon he came into our yard and showed me his fingernails, yellow and hard. He held them out quivering, as if he were going to do a hocus-pocus magic trick, and when he said it was cancer, I flinched. When I looked up into his face, pale as a fistful of straw, I saw that his eyes were large and bluish, his face already sinking in disease. I was eating grapes, feeding them into my mouth, and I didn't know what to do about his dying except to offer him some of my grapes. He laughed at this. He walked away, straight as any other man, and returned to his yard where he talked to himself and revved up a boat engine clamped to a barrel. A scarf of smoke unfurled from the engine, and the blackish water boiled. He didn't seem to be getting anywhere.

That summer we did our rough living on the street, and our dogs did too. When my uncle Junior's collie got hit by a car on Van Ness Avenue, I watched my uncle, a teenager with a flattop haircut, gather his dog into his arms. He was the bravest person I knew, for he hugged to his chest what he loved best. A few of the kids from Braly Street milled around; the barber came out from his shop, snapped his sheet as if in surrender, and stared at the commotion for a moment, his eyes the color of twilight itself.

Uncle Junior yelled at us to get away, but I shadowed him for a while, barefoot and pagan. He walked up the alley that ran along our dusty-white house. I didn't know then that he intended to wait out the last breaths and 
then bury his dog. I didn't know that months later at the end of this same alley we were walking down, a car would roll, its wheels in the air, the man inside dead and his hat as flat as cardboard. I would be excited. Like my uncle's collie, I panted, except from exhilaration, when the police asked if we knew the person. I pointed and said that he lived near the man with the motorboat engine and cancer.

This was the summer I began to worry about disease. My father was in road camp with my uncle Shorty. They'd gotten drunk and stolen a car, but I was behaving. I drank my milk, ate my Graham Crackers, and dutifully picked slivers from my palm, but despite my hygiene, I was involved in disease. One morning my brother woke with his throat pinched with a clot that made it difficult for him to swallow. He opened his mouth in the backyard light and, along with my mother, I looked in, worried that I would have to wallow in the same bedroom and, in time, the same disease. His mouth was like any other mouth, wet with a push of milky air. But our mother knew better: the tonsils would have to come out. Mine would have to come out, too, no matter how many times I swallowed, cried, and said, "See, Mom, I'm OK." She figured that if you do one son you might as well do two.

That night I stood by the window in our bedroom and ate $M \& M$ candies and wondered about Father and Uncle Shorty. They were in a sort of prison camp, I knew. We had gone to see them, and father had shown me his hands, which were speckled white with paint. I rode on his knee, a camel ride of excitement because I was chewing gum and sunflower seeds at the same time. I asked him when he was coming home. Pretty soon, he answered. I didn't know that he and my uncle were painting rocks along rural Kearny Boulevard and hoisting railroad ties that became bumpers in the gravel parking lots of Kearny Park.

I thought about them as I ate my M \& Ms and touched my throat when I swallowed the candy. Father wasn't there to help me. He was far away, it seemed, and I peered out the window toward the junkyard, with its silhouette of pipes, plumbing, and jagged sheet metal, the playground of my childhood. The summer wind picked up the metallic scent and whipped it about. When a sweep of headlights from the cars that turned from Van Ness onto Braly Street frisked the junkyard, the eyes of its German Shepherd watchdog glowed orange and stared at me. I ate my candy, one last taste of sweetness on the eve of blood and gagging. 
When we arrived at the community hospital, I hugged my pajamas and coloring book. I glanced nervously down the corridor. I looked at the old people's yellow fingernails, clear signs of cancer, and I peeked in a lab where I knew that blood was drawn. My brother and I walked on each side of our mother. We were led to a room where there was another child sitting up in a crib-like bed, mute as a teddy bear. He spit red into a bowl, and I immediately knew this was a scary place.

After we settled into our room, I worried not about dying, but about the filthy act of baring my bottom to a bedpan. I was in a hospital gown, not my pajamas. I held out for hours, but when I couldn't stand it anymore, I told the nurse I had to use the bathroom. She wouldn't allow me to get up from bed. I started to cry, but she scolded me, and I knew better than to carry on because she had the instruments of pain. I told my brother not to laugh, but he was too scared to entertain the thought. I squatted on the bedpan and was letting my water flow when a blind, teenage girl walked past our open door, a ghost-like figure blowing down the corridor. A nurse was helping her along, step by hesitant step. I wanted to ask the nurse if she was blind forever, or would she one day peel off that bandage and smile at every bloodshot color in the precious world. I did my number and then looked over at the boy, now asleep and pale as an angel.

I don't recall my brother and me talking much at the hospital. I lay in bed, touching the plastic wrist band with my typed name. I closed my eyes. I tried to shut out the image of the "thing" they would take out of my throat, a kidney-bean sac no longer needed. I knew that my baby teeth would eventually loosen and come out, possibly when I was biting into a peach or an apple, but I was terrified that someone behind a white mask would probe my mouth.

A few hours later, my brother was wheeled away with tears brimming in his eyes. If my big brother had dime-size tears in his eyes, then I, his little brother with just baby teeth, would have silver dollars rolling down my cheeks. I considered crying and sobbing as pitifully as I could manage, but who would listen? My mother was gone, a tiny egg of memory living inside my head. Now my brother was gone. I looked over to where the other boy was, but his parents had come and rescued him. I didn't have anything to do except thumb through my animal coloring book and imagine what crayons I would use on the deer, elephant, giraffe and grinning hyena. This diversion helped. But then I was wheeled away. 
This was the late '50s when almost every child's tonsils were routinely clipped from his throat. I remember the room where a nurse in a mask lowered a disc-like mask onto my nose and mouth. She lowered it three times and each time said, "breathe in" as they basted my face with ether. I did what I was told until my consciousness receded like a wave, and I was in a room full of testing patterns, something like television when it was still too early for cartoons. They operated, and I bled into a bowl all night, it seemed, but happily drank 7-Up with no ice, a treat that didn't cost me anything except hoarse speech for three days.

When Rick and I got home, we were pampered with ice cream and 7-Up, a lovely blast of carbonation which singed my nostrils. I believed that we might continue to live our remaining childhood that way with mounds of ice cream, 7-Up, and cooing words from our mother. But too soon that stopped, and we were back to the usual plates of frijoles and tortillas. At that time, while my father and uncle were in jail, my mother worked at Readi-Spud, peeling potatoes that scurried down troughs of icy water. She would give us over to Mrs. Molina, the mother of at least nine children and the jolliest woman in the western world. She laughed more than she spoke, and she spoke a lot. While in Mrs. Molina's care, I became even more worried about disease because I knew roaches made a princely living in her cupboards.

Mrs. Molina worked at a Chinese noodle factory and came to get Rick and me after work. One day, when we climbed into the back seat of her station wagon, her son Donald was standing in a cardboard tub of noodles. His feet pumped up and down and emitted a sucking sound with each marching step. When I asked Mrs. Molina about dinner she was laughing because the baby on the front seat was crawling toward her breast. She giggled, "You like chow mein?" I slowly lowered my gaze to Donald's bare feet and felt sick.

They ate noodles right after we arrived, slurped them so that the ends wiggled like worms into their suctioning mouths. My brother and I ate grapes and drank water. Later, all of us-eleven kids-played our version of "The Old Woman Who Lived in a Shoe." We climbed onto the roof and jumped off, a cargo of unkillable kids hitting the ground like sacks of flour. It may not have been that same evening, but I recall three babies at the end of a long, dirty hallway and some of the kids, the older ones, trying to knock them over with a real bowling ball. There was squealing and crying, 
but it was mostly laughter that cut through the cloistered air of a dank hallway, laughter coming even from Mrs. Molina when one of the babies went down.

One untroubled afternoon Lloyd showed me a toy rifle, the kind that you had to crack in half to cock and which shot arrows tipped with red suction cups. He took one suction cup off, cocked the rifle, and shot the arrow into the flat spatula of his palm. "It doesn't hurt," he told me, and let me shoot the arrow repeatedly into my palm, the pressure of the arrow no more than a push. He recocked the rifle and fit the arrow into one of his nostrils. I automatically stepped back even though Lloyd was smiling. He was smiling just a moment before he pulled the trigger, before blood suddenly streamed from his nose and his eyes grew huge as two white moons and full of fright. He started crying and running around the house with the arrow in his nose, and I ran after him, almost crying. When his mother caught him by the arm, I raced out of the house, not wanting to get involved, and returned home, scared as I touched my own nose. I imagined the arrow in my own nose. I imagined blood spilling on the back porch. Later, just after I had finished dinner, I returned to Lloyd's house. He was at the table, with the threads of cotton balls hanging from his nostrils. The family was eating chow mein, piled like worms and wiggling down their throats.

The house was a poor, curled shoe, and it scared me because in its carelessness lurked disease and calamity. I recall standing at their stove and asking a teenage boy who had drifted inside the house, "What's that you're making?" I looked at a large, dented kettle containing a grayish soup which Arnold was stirring with a pencil. I peeked into the soup, sipped it with a large spoon, and saw small things wheeling in the water as he stirred them-a merry-go-round of meats, I thought. When he said, "pigeons," I looked closely and could see the plucked birds bob and rise, bob and rise, and with each rise I could see the slits of their closed eyes.

The Molina place, however, was not nearly as scary as the hospital. There were no instruments of pain, unless you counted the hive of tapeworms that showed up later because I ate raw bacon, white strips we peeled like Band-Aids from the wrapper. The Molinas taught me this too; they said it was good, and I ate my share while sitting on the roof, the sunset a stain the color of bright, bright medicine. How I would need that sun! How I would need a cure for my worry, and a cure for my brother, who was sporting on the bottom of his foot a sliver the size of a chopstick. 
At age six disease scared me, and so did Grandpa, who lived just down the alley from our house on Braly Street. When I went over to eat lunch-yet another pile of frijoles wrapped in a diaper-size tortilla-he was at the kitchen table playing solitaire with a big chunk of his head missing. I backed out of the house, bristling with fear, because the only thing left was his face. He looked like the poker-face card in front of him: Jack of Bad Luck, or King of Almighty Mistakes? While I backed out of the screen door, Uncle Junior caught me from behind and nudged me into the kitchen. He told me that Grandpa was wearing a nylon stocking on his head, trying to grow his hair black. A stinky concoction of yerba buena and earthly fuels smothered his crown and temples. I sat down and ate my beans while watching Grandpa eat from his plate. I asked him if his head would grow back; he was chewing a huge amount of food like a camel. I thought I would turn seven by the time he cleared his throat and heard his answer, which was, "Mi'jo, you got beans on your shirt. Shaddup."

Two kittens died from distemper and then Pete, our canary, was devoured by mama cat. A stray dog showed up outside our yard with a piece of wood in its watery eye. I touched my own eye, pulling at a tiny string of sleep. Everything seemed ill and ominous. Even our house began to slip on its foundation, which excited me because the bathroom was now at a slant. The water in the tub slouched now that one side was higher. With a scoop of my hands, it was easy to force a tidal wave on the line of ants scurrying along the baseboard.

I looked around at family and friends who were hurt or dying, but I didn't know that a year later my father would die, his neck broken in an industrial accident. This would be in August, when we were settled in a new house the color of cement. He didn't live in that house more than a week, and then he was gone. The funeral didn't mean much to me. It was the scent of flowers and the wash of tears; it was a sympathic squeeze of my shoulders and candies slipped into the pockets of my tweed coat, which was too small because it was borrowed. After his burial I recall eating donuts at my grandparents' house. When a doctor was called because Grandma was in hysterics, I didn't stop eating. I took what was rightly mine and devoured it in the dark, near the ugly claw-like crowns of a rose bush.

I didn't know what to think except that Father was out of prison and now in the earth forever. Because he wasn't returning, I began to play with his squeaky hand drill, boring into trees and fences. I liked the smell of the 
blond shavings and liked to think that maybe Father used the drill in prison. He mostly painted rocks, this much I was told, but I fantasized about how he might have used it in prison to get away. I saw him poking holes in a cement wall and then pushing over that wall to get Uncle Shorty in the adjacent cell. Uncle Johnnie was there, too, a ghost-like bundle of flesh on the cot. My father was going to save not only the both of them, but in the end himself as well.

Occasionally, we would visit my father's grave, where my mother cried and set flowers, half-shadowing the oval photo on his grave. What worried me was not his death, but the gold-painted cannon on a hill that pointed at our Chevy when we drove through the cement gates. The cannon scared me because my vision of death was that when you died an angel would pick you up, place your head in the cannon, and give your neck a little twist. I was spooked by this cannon and wanted to ask my mother about it, but she was too busy in her sorrow for a straight answer. I kept quiet on the matter. I figured there was one cannon, like one God, and all graves rolled on a hill. In time, you were asked to put your head in the cannon and die as well.

I didn't realize that I was probably ill. Neither did I realize how I used my time when my mother would send me off to school. For weeks, I didn't go there. I stayed in an alley, kicking through garbage and boredom, and returned home only after I assumed my classmates had finished with whatever the teacher had asked them to do. Sometimes I would take the drill and make holes, occasionally even into the lawn. But I had grown bored with this. I had discovered how I could make a huge noise. In the empty bedroom, the one my father and mother would have used, I spent hours with fistfuls of marbles. I bounced them off the baseboard, a ricochetting clatter that I imagined were soldiers getting their fill of death. The clatter of noise busied my mind with something like hate. If I had looked into a mirror, I would have seen this hate pleated on my forehead. If anyone, including my sister or brother, had smarted off to me, I had plans to get even. I would let them go to sleep and then blast them with marbles at close range as they inhaled a simple dream.

My mother was alone, and in her loneliness she often piled us into our Chevy and drove us over to my nina's house on the west side of Fresno, a place that was so scary that even the blacks were afraid. My ninagodmother-took in identical twin boys, same age as me but filthier. Their dirty hair was like the hair Woody Woodpecker wore. They were orphans. 
They were sadly nicknamed "Caca" and "Peepee," and for a while they made me feel good because I knew they were poorer than me. "Peepee, is your dad dead?" I would ask. "Caca, what grade are you in?" I would inquire. They shrugged their shoulders a lot and ran when they saw my nina, a woman you dared not play with. Every time we visited, I took a toy to show them-plastic plane, steel car, sock of marbles, and even my brother's glow-in-the-dark statue of Jesus. I wanted them to know that even though my father was dead, I still owned things. After a few visits I didn't have anything left to share, just a ten-foot link of rubber bands. This lack made me mad, and I began to pick on them, even beat them up, in a kind of Punch-and-Judy show in the dirt driveway. When we found out that the twins were scared of ghosts, my brother and Rachel, my nina's daughter, told them to sit and wait in the living room because their mother and father were going to pick them up. We gave them fistfuls of raisins. Rick and Rachel then ran outside, where they scraped a bamboo rake against the window. The twins looked at me, then the curtain that was dancing like ghosts from the blast of the window cooler. Their mouths stopped churning on those raisins and the gray light of the TV flashed briefly in their eyes. When I yelled, "La llorona is outside," they jumped and ran from the house, poor, terrified "Caca" and "Peepee" living up to their names that early evening.

I often attended church, a place that was scarier than the hospital or the Molinas's house or grandfather's head. Mother said that Jesus had been a good man, and he wanted peace and harmony in the hearts of all men. She said this while I looked at Jesus on his cross, poor Jesus who had nails and blood all over him. If they did that to someone who was so good I wondered what they might do to me. You see, I was turning out bad. I was so angry from having to worry all the time that I had become violent. Once I stuck a broken shaft of bottle in my brother's leg for going swimming without me. Blood ran down my knuckles, and I ran away amazed that it was so calming to hurt someone who was bigger. My mother beat me with a hanger for my violence and then made me eat dinner in the bathroom. I put my bowl first on the hamper, then moved it to my knees, because I wanted a better view of the faucet dripping water. In the bathroom, then, I began to worry about our wasting water. I counted the drips to a hundred. I swallowed and pictured in my mind a pagan baby sucking a rock for moisture. Later, after I was allowed out of the bathroom, I took a pair of 
pliers and tried to tighten the faucet. I managed only to scratch the chrome plating on the handles, and I went to bed worrying that my mother would conclude that it was me. I closed my eyes and let the pagan baby swallow the rock.

I asked my mother if you ever had to stop worrying, or if you had to continue until you were old. I was already tired of having to learn about Jesus and the more important apostles. She answered yes and mumbled something about life not being easy. This was when I began to look at pictures in the medical dictionary: ringworm, rickets, TB, tongues with canker sores, and elephantiasis. With elephantiasis, the scariest disease, your legs swelled fat as water balloons and, I suspected, sloshed some evil liquids. I looked down at my own legs, those reeds of bone and marrow. They were skinny, but still I worried that my legs could swell and the rest of me, arms mainly, would stay thin, possibly from rickets which had made headway at school. I would be the second deformed kid on our street, the other being an older boy with one small arm that was shaped like a banana.

I knew the face of the boy in the iron lung. His hair was black and his eyes flat. He was motherless, for who could wrap a loving hug around a machine large as a barrel. I could hardly look at this boy. He might have shared my name, or my brother's name, or been related to the kid at school who had one leg shrunken from polio. I didn't like the idea of living lying down for what might be forever. Still, I practiced what he lived by lying still on the couch until I fell asleep. When I woke I didn't know if I was at the new house or the old house, or if an angel had already picked me up and fit my head in the gold-painted cannon.

Then I worried about air and radiation and religious equations like the Trinity and, finally, the march of communists against our country. The hollowness in my face concerned my mother. She studied me when I did my homework at the kitchen table. She suspected that I might have ringworm because there were pale splotches on my face. It was only dirt, though, a film of dirt that you could rub off with spit and a thumb.

My worry lessened when I began to understand that nothing could really hurt me. It was another summer and the beginning of the '60s. On our new street, which was green with lawns and squeaky with new trikes, I discovered my invincibility when I was running with new friends, barefoot, and with no shirt. I was particularly proud because I had hooked a screwdriver in a belt loop on my pants. I tripped and fell, and as I fell I 
worried for a moment, wondering if the screwdriver would drive its point into my belly. The fall was slow, like the build-up to my seven years, and the result would be either yes or no to my living.

The screwdriver kicked up sparks when it cut across the sidewalk. They were wonderful, these sparks that lasted no longer than a blink. Right then, with gravel pitted in my palm and my belly spanked by the fall, I rolled onto my back, cried, and knew that hurt and disease were way off, in another country, one that thanks to Jesus Almighty, I would never think to visit. 